\title{
ENVIRONMENTAL ISSUES IN THE ALLOCATION AND MANAGEMENT OF WESTERN INTERSTATE RIVERS
}

\author{
Reed D. Benson ${ }^{1}$
}

This special issue focuses on a range of topics relating to Great Lakes water and the environment, including the Great Lakes-St. Lawrence River Basin Water Resources Compact (Great Lakes Compact). This interstate agreement, approved by Congress in $2008,{ }^{2}$ represents one of the more important recent developments in water policy, not just in the Great Lakes, but nationally as well. ${ }^{3}$

There are many interstate water compacts, primarily in the western United States, ${ }^{4}$ but the Great Lakes Compact is unique. From a western perspective, what makes this new compact so unusual is that it actually restricts diversions for consumptive uses for purposes of protecting the Great Lakes environment. ${ }^{S}$ The western compacts essentially take the opposite approach, emphasizing old-school water development and use, while mostly ignoring environmental matters. ${ }^{6}$ In practice, the water development favored by these compacts-chiefly in the form of large federal water projects-sharply altered western river ecosystems, resulting in serious environmental problems. ${ }^{7}$ These problems have not prompted changes in the compacts (or Supreme Court decrees) that formally allocate interstate waters among the western states. But largely because of the

1. The author thanks Prof. Eric Dannenmaier and the students at the Indiana University Robert H. McKinney School of Law for inviting him to speak at their fine symposium. Prof. Benson is also grateful to the Keleher \& McLeod endowment and the UNM School of Law for their financial support of the work that went into this essay.

2. Great Lakes-St. Lawrence River Basin Water Resources Compact, Pub. L. No. 110342, 122 Stat. 3739 (2008).

3. See, e.g., Noah D. Hall, Toward a New Horizontal Federalism: Interstate Water Management in the Great Lakes Region, 77 U. COLO. L. REV. 405, $406-07$ (2006) (explaining that the not-yet-ratified Great Lakes Compact represented a promising new model for federalism in water policy and management).

4. As Prof. Doug Grant, one of the leading authorities on interstate water compacts, wrote in 2003 , "[w]estern states are the main participants in water allocation compacts. At least one western state is a party to every compact except the two most recent ones, and western states comprise all of the signatory parties in eighteen compacts." Douglas L. Grant, Interstate Water Allocation Compacts: When the Virtue of Permanence Becomes the Vice of Inflexibility, 74 U. CoLo. L. REv. 105, 105 (2003) (alteration added).

5. See Hall, supra note 3 , at $432-45$ (describing the Great Lakes Compact's restrictions on new or increased water withdrawals, largely tied to the need to protect and improve the Great Lakes ecosystem).

6. See Grant, supra note 4, at 105-6.

7. Id. 
requirements of the Endangered Species Act (ESA), ${ }^{8}$ environmental issues have indeed become a factor in the management of western interstate rivers.

This essay briefly examines environmental issues in the allocation and management of western interstate rivers. Part I provides background on interstate water allocation in the West, on western water projects built by the U.S. Bureau of Reclamation (the Bureau), and on the resulting environmental problems facing western rivers. Part II examines one Supreme Court decree and two compacts apportioning the waters of three western rivers, to illustrate how interstate water allocation has addressedor more accurately, not addressed-environmental concerns. Part III explains how the need for ESA compliance has influenced the management of these three western rivers, and considers the relationship between these environmental developments and the compacts and decrees that formally allocate interstate waters.

\section{ALLOCATION AND DEVELOPMENT OF THE WATER OF INTERSTATE RIVERS}

This section provides a short overview of the standard legal mechanisms-Supreme Court decrees and, more commonly, interstate compacts-for allocating the water of rivers shared by two or more states. It then very briefly explains how interstate rivers were "developed" through major federal water projects built in the 20th century, and how this development contributed to significant environmental problems, including impacts to river-dependent species that are now protected by the ESA.

\section{A. Interstate Water Allocation: Supreme Court Decrees and Interstate Compacts}

The western United States has many rivers that form or cross state boundaries, and many of these rivers have been formally apportioned among the states that share them-that is, the waters of these rivers have been allocated among the states under a recognized legal mechanism. The principal approach is the interstate compact, a negotiated agreement that becomes both state and federal law upon ratification by the relevant state legislatures and Congress, respectively. ${ }^{9}$ In the absence of a compact, the U.S. Supreme Court may divide the waters of an interstate river under the doctrine of equitable apportionment. ${ }^{10} \mathrm{~A}$ third approach, Congressional

8. Endangered Species Act, 16 U.S.C. $\S \S 1531-1544$ (2013) (through P.L. 113-31).

9. Joseph L. SAX ET AL., Legal CONTROL OF WATER ResOuRCES 726 (3d ed. 2000).

10. See generally A. Dan Tarlock, The Law of Equitable Apportionment Revisited, Updated and Restated, 56 U. CoLo. L. REV. 381 (1985). 
apportionment, has been used only once. ${ }^{11}$

The doctrine of equitable apportionment dates to the early 20th century, when the Supreme Court ruled that it could decide water allocation disputes between states, ${ }^{12}$ and declared that one state could not cause harm to another "to the extent of destroying the equitable apportionment of benefits between the two States resulting from the flow of the river."13 Despite the importance of this basic principle of interstate equity, however, the Court has entered apportionment decrees for only three rivers, and the last was nearly seventy years ago. ${ }^{14}$

By contrast, there are more than two-dozen compacts involving interstate rivers, mainly in the west. ${ }^{15}$ The terms of these compacts vary widely, reflecting a range of basin-specific physical characteristics, water supplies and demands, and policy priorities of the signatory states. The compacts run the gamut in their approaches to allocating water, for example: the Colorado River Compact divides the river's flow between the multistate "Upper" and "Lower" Basins without apportioning a specific portion to any one state, ${ }^{16}$ whereas the Upper Colorado River Basin Compact gives a certain percentage of the basin's water to each of four states, ${ }^{17}$ and the Bear River Compact is highly detailed in allocating water to specified sub-state areas in times of shortage.$^{18}$ Some compacts, such as the Arkansas River Compact, operate largely by restricting post-compact water development activities in the upstream state ${ }^{19}$ One nearly universal feature of all but the oldest compacts, however, is a "compact commission" composed of representatives from all the participating states (and usually

11. In a famous case, a divided Supreme Court declined to equitably apportion the waters of the Lower Colorado River among Arizona, California, and Nevada, holding that Congress had already effected an allocation in enacting the 1928 Boulder Canyon Project Act. See generally Ariz. v. Cal., 373 U.S. 546 (1963).

12. Kan. v. Colo., 206 U.S. 46, $81-84$ (1907).

13. Id. at 118.

14. SAX ET AL., supra note 9, at 749-52 (describing the Court's decisions apportioning the waters of the Laramie (1922), Delaware (1931), and North Platte (1945) rivers).

15. As of 2007 , there were 26 interstate water compacts, mostly involving western states. See Jerome C. Muys et al., Utton Transboundary Resources Center Model Interstate Water Compact, 47 NAT. RESOURCES J. 17, 21 (2007).

16. See Colorado River Compact, CoLo. REv. STat. § 37-61-101, art. III (2012).

17. Upper Colorado River Basin Compact, ch. 47-48, art. III, 63 Stat. 31, 32-33 (1949).

18. Bear River Compact, Pub. L. 85-348, art. IV, 72 Stat. 38, 41-43 (1958).

19. See generally Arkansas River Compact, ch. 155, 63 Stat. 145 (1949). Article IV.D of this compact contemplates future water development activities within the Arkansas River Basin, provided that river flows "shall not be materially depleted in useable quantity or availability for use to the water users in Colorado and Kansas under this Compact by such future development or construction." Id. at art. IV.D. This restriction would be key to later Supreme Court litigation over Colorado's compliance with the compact. See Kan. v. Colo., 514 U.S. 673 (1995). 
the federal government as well), charged with administering the compact. ${ }^{20}$

Nearly all of the west's water compacts date from the 1920s through the 1950 s, with most enacted after $1945 .{ }^{21}$ It is no mere coincidence that the boom in interstate compact formation was happening at around the same time as the boom in federal water project construction. ${ }^{22}$ As stated by one authority,

It has been suggested that "[m]ost compacts represent compromises reached by the water resource establishments of the signatory states against a background of urgent need (or at least desire) for federal benefits that are contingent upon agreement being reached." ... The federal benefits typically were the funding and building of water development projects using interstate waters, projects that by common understanding were not likely to be funded by Congress absent agreement by the affected states regarding allocation of the interstate waters. ${ }^{23}$

In other words, the states were motivated to enter water compacts largely in hopes of securing authorization and funding for major federal water projects, and Congress delivered dozens of such projects in the middle part of the 20 th century. ${ }^{24}$

20. See A. Dan Tarlock et al., Water Resource Management 978 (6th ed. 2009). For example, the Upper Colorado River Basin Compact and the Klamath River Basin Compact provide for a commission with one representative from each state and a federal representative who will serve as chair. See Upper Colorado River Basin Compact, ch. 47-48, art. VIII.A, 63 Stat. 31 (1949); Klamath River Basin Compact, Pub. L. No. 85-222, arts. IX.A.1, IX.A.2, 71 Stat. 497, 502-503 (1957). Unlike the Upper Colorado Commission, however, the federal representative on the Klamath Commission has no vote. See id.

21. Four western water compacts were adopted from the 1920 s through the $1930 \mathrm{~s}$, six in the 1940s, six in the 1950s, and two in the 1960s. Grant, supra note 4, at 106 n. 10.

22. '[O]f Reclamation's more than 180 projects, about 70 were authorized before World War II. The remainder were authorized during and after World War II in small and major authorizations, such as the Pick-Sloan Missouri Basin Program (1944), the Colorado River Storage Project (1956), and the Third Powerplant at Grand Coulee Dam (1966)." U.S. Bureau of Reclamation, Brief History: Bureau of Reclamation 5, archived at http://perma.cc/0Sby2gTcAKj (alteration added).

23. Douglas L. Grant \& Gregory S. Weber, Cases and Materials on Water LaW 495 (8th ed. 2010) (quoting Charles J. Meyers, The Colorado River, 19 STAN. L. REV. 1, 48 (1966)) (alteration in original).

24. See Marc Reisner, Cadillac Desert 145-68 (rev. ed., Penguin Books 1993) (1986). Reisner traced the pace of federal water project development in the fifty-plus years following the enactment of the 1902 Reclamation Act:

Within its first thirty years, [the Bureau] had built about three dozen projects.

During the next thirty years, it built nineteen dozen more. . . By 1956, Congress had voted 110 separate authorizations for the Bureau of Reclamation, some encompassing a dozen or more irrigation projects and 


\section{B. Interstate Rivers in the West: Water Development and Associated Environmental Problems}

As interstate compacts shaped the legal landscape on many of the western United States' rivers, federal agencies-especially the Bureau of Reclamation-altered the physical landscape. Congress launched the federal reclamation program in 1902, enacting a statute ${ }^{25}$ that authorized the Interior Secretary to build "irrigation works for the storage, diversion, and development of waters" ${ }^{\prime 26}$ in the western states and territories. As originally conceived, these projects would supply irrigation water to farmers who would settle on designated lands and "reclaim" them for irrigated agriculture, repaying the government's construction costs over a ten-year period. ${ }^{27}$ By 1939 , Congress had recognized that reclamation projects could serve multiple purposes, including hydropower, flood control, navigation, municipal water supply, and other "miscellaneous purposes." ${ }^{28}$ As stated by historian Donald Pisani, "[n]ot until the 1930s, when the 'High Dam Era' gave the bureau responsibilities for providing water to cities as well as farms, did it become the most important federal agency in the West. From 1930 to 1970 the water and power provided by the bureau transformed the region....,29

The Bureau today operates over 330 dams, storing and releasing water for irrigation, hydropower, drinking water, and other human uses. ${ }^{30}$ Operation of these dams, however, creates a variety of serious and ongoing environmental impacts throughout the west. Most notably, reservoir

dams. Of these, seventy-seven-nearly three-quarters-were authorized between 1928 and $1956 .$. . In that astonishingly brief twenty-eight-year period between the first preparations for Hoover Dam and the passage of the Colorado River Storage Project Act, the most fateful transformation that has ever been visited on any landscape, anywhere, was wrought.

Id. at 165-66 (alteration in original).

25. Act of June 17, 1902, ch. 1093, 32 Stat. 388 (codified in scattered sections of 43 U.S.C. from $\S \S 371$ to 498$)$.

26. Id. $\S 2$ (codified at 43 U.S.C. $\S 411$ ).

27. Id. $\S \S 4-5$ (codified at 43 U.S.C. $\S \S 392,419,431$, and 439).

28. Reclamation Project Act of 1939, ch. 418, § 9(a), 53 Stat. 1187, 1193 (1939) (codified at 43 U.S.C. $\S 485 \mathrm{~h}(\mathrm{a})$ ).

29. Donald J. Pisani, Federal Reclamation in the Twentieth Century: A Centennial Retrospective, in THE BUREAU OF RECLAMATION: HISTORY ESSAYS FROM THE CENTENNIAL SyMPOSIUM Volumes I AND II 611 (2008), archived at http://perma.cc/0Uovc6MPvhY (alteration added).

30. See Bureau of Reclamation Facts \& Information, BUREAU OF RECLAMATION, http://www.usbr.gov/main/about/fact.html (last updated June 13, 2013, archived at http://perma.cc/0wZBa3CgTB9). The Bureau claims that its facilities deliver irrigation water to ten million acres and one-fifth of the west's farmers, generate an average of forty billion kilowatt-hours of electricity per year-making the Bureau the nation's second largest hydropower producer, provide municipal water supplies serving thirty-one million people, and host ninety million visitor-days of recreation. $I d$. 
operations change the quantity, quality, and timing of downstream river flows, often damaging aquatic ecosystems and harming native species. ${ }^{31}$ Indeed, a 1996 study of counties in the western United States "found that the number of ESA-listed fish species in a county correlated positively with the level of irrigated agriculture reliant on surface water in the county. In particular, the number of species depended positively on water-supply levels of the Bureau of Reclamation., 32

The ESA has become a significant factor in the operation of several Bureau projects, not only because the operation of many projects affects protected species and their habitats, but also because $\S 7$ of the ESA

31. See Brian D. Richter \& Gregory A. Thomas, Restoring Environmental Flows by Modifying Dam Operations, 12 ECOLOGY AND SOC'Y, no.1, 2007, at art. 12, archived at http://perma.cc/0mboN5Ri4Zd. Richter and Thomas summarize the typical downstream effects of dams (not necessarily Bureau dams) as follows:

Of all the environmental changes wrought by dam construction and operation, the alteration of natural water flow regimes has had the most pervasive and damaging effects on river ecosystems and species (Poff et al. 1997, Postel and Richter 2003). Below we discuss the ways that dam operations induce hydrologic changes, the nature of which is strongly influenced by the operating purposes of the dam. Dams can heavily modify the volume of water flowing downstream, change the timing, frequency, and duration of high and low flows, and alter the natural rates at which rivers rise and fall during runoff events. Although much has been written about the ecological consequences of hydrologic alteration, Bunn and Arthington (2002) summarize their review of this literature by highlighting four primary ecological impacts associated with flow alteration: (1) because river flow shapes physical habitats such as riffles, pools, and bars in rivers and floodplains, and thereby determines biotic composition, flow alteration can lead to severely modified channel and floodplain habitats; (2) aquatic species have evolved life history strategies, such as their timing of reproduction, in direct response to natural flow regimes, which can be de-synchronized through flow alteration; (3) many species are highly dependent upon lateral and longitudinal hydraulic connectivity, which can be broken through flow alteration; and (4) the invasion of exotic and introduced species in river Id. systems can be facilitated by flow alteration.

32. Michael R. Moore et al., Water Allocation in the American West: Endangered Fish Versus Irrigated Agriculture, 36 NAT. RESOURCES J. 319, 348 (1996). The Bureau, however, was not the only federal agency to build major water projects that would transform western rivers. The U.S. Army Corps of Engineers also played its part, and Marc Reisner's CADILLAC DESERT described the Corps' historic competition with the Bureau over projects in a chapter memorably titled "Rivals in Crime." Reisner, supra note 24, at ch. 6 . The Corps' primary mission in building and operating dams has been flood control, but the Corps' floodcontrol operations have sometimes been the focus of major disputes. On the Missouri River, where the Corps operates a system of dams that affect a variety of uses in several states, there was intense litigation in the mid-2000s on a range of issues including impacts on endangered species. See In re Operation of Mo. River Sys. Litig., 421 F.3d 618 (8th Cir. 2005). 
requires all federal agencies to "insure" that their actions are "not likely to jeopardize the continued existence" of any listed species. ${ }^{33}$ This command has forced the Bureau to change the way it operates some projects, including providing more water for species while cutting deliveries to irrigators who have water supply contracts with the Bureau. ${ }^{34}$ The Klamath Basin water crisis, where many farmers on one of the oldest reclamation projects lost nearly their entire water supply in drought year 2001, was perhaps the most intense dispute. ${ }^{35}$ The nation's hottest endangered species conflict today involves the federal Central Valley Project in California, pitting the needs of endangered salmon and Delta smelt against traditional water uses, primarily irrigation. ${ }^{36}$ ESA requirements in the Central Valley have been heavily litigated for two decades, ${ }^{37}$ and the cases show no sign of stopping. $^{38}$

Thus, the mandate in $\S 7$ of the ESA has forced the Bureau to consider environmental factors in operating its projects that affect listed species. Outside this narrow context of federal water projects and endangered species, however, environmental factors have had relatively little effect on the allocation and management of interstate rivers, as the next section discusses.

\section{ENVIRONMENTAL ISSUES IN WESTERN INTERSTATE WATER DECREES AND COMPACTS}

This section discusses the treatment of environmental issues in the decrees and compacts that apportion the water of interstate rivers. Due to space constraints, this article does not attempt a comprehensive review of the subject, but uses one decree and two compacts to provide an illustrative

33. 16 U.S.C. $\S 1536(a)(2)(2013)$.

34. Dave Aiken, Balancing Endangered Species Protection and Irrigation Water Rights: The Platte River Cooperative Agreement, 3 Great PlaINS Nat. RESOURCES J. 119 , 126 (1999).

35. See Holly Doremus \& A. Dan Tarlock, Water War in the Klamath Basin: MaCHO LAW, COMBAT BIOLOGY, AND DiRTY POLITICS 1-4 (2008).

36. See generally Central Valley Project, U.S. DEP'T OF JUSTICE, http://www.justice.gov/ enrd/4707.htm (last updated June 2013, archived at http://perma.cc/073RT39B9SY).

37. See, e.g., O'Neill v. United States, 50 F.3d 677 (9th Cir. 1995) (USBR authority to reduce water deliveries to comply with ESA); Madera Irrigation Dist. v. Hancock, 985 F.2d 1397 (9th Cir. 1993) (application of ESA to water contract renewals); Tulare Lake Basin Water Storage Dist. v. United States, 49 Fed. Cl. 313 (2001) (ESA restrictions on water deliveries as taking of property).

38. See, e.g., Natural Resources Defense Council v. Salazar, 686 F.3d 1092 (9th Cir. 2012) (applicability of ESA to certain water supply contracts); Consol. Delta Smelt Cases, 717 F. Supp. 2d 1021 (E.D. Cal. 2010); Consol. Salmonid Cases, 713 F. Supp. 2d 1116 (E.D. Cal. 2010) (both addressing validity of ESA biological opinions regarding Central Valley Project operations). 
look. As shown by the following three river basins, the water of interstate rivers has been allocated with little or no regard for environmental concerns.

\section{A. Equitable Apportionment: the North Platte River}

One of the Supreme Court's most important equitable apportionment decisions $^{39}$ divided the waters of the North Platte River, primarily between Wyoming and Nebraska. In a factually detailed opinion, the Court apportioned the waters of the North Platte-most importantly, a "pivotal reach" of forty-one river miles ending just below the Wyoming-Nebraska border-allocating 75 percent of irrigation season flows to Nebraska and 25 percent to Wyoming. ${ }^{40}$ Outside of those two states, however, this 1945 case is best known for its general statement of the many factors the Court may consider in making an equitable apportionment determination regarding the waters of an interstate river. ${ }^{41}$

The Court's exhaustive consideration of these factors in Nebraska $v$. Wyoming, however, focused solely on a single use of water: irrigation. The Court began its opinion by stating, "The controversy pertains to the use for irrigation purposes of the water of the North Platte River, ${ }^{, 42}$ and devoted forty pages of factual, legal, and equitable analysis exclusively to irrigation. ${ }^{43}$ Thus, despite its famous statement fourteen years earlier in an eastern equitable apportionment case-" [a] river is more than an amenity, it

39. Neb. v. Wyo., 325 U.S. 589 (1945).

40. Id. at $637-54,667-69$.

41. In allocating water among two states that follow the doctrine of prior appropriation, the Court stated:

So far as possible those established uses should be protected though strict application of the priority rule might jeopardize them. Apportionment calls for the exercise of an informed judgment on a consideration of many factors. Priority of appropriation is the guiding principle. But physical and climatic conditions, the consumptive use of water in the several sections of the river, the character and rate of return flows, the extent of established uses, the availability of storage water, the practical effect of wasteful uses on downstream areas, the damage to upstream areas as compared to the benefits to downstream areas if a limitation is imposed on the former-these are all relevant factors. They are merely an illustrative not an exhaustive catalogue. They indicate the nature of the problem of apportionment and the delicate adjustment of interests which must be made.

Id. at 618 .

42. Id. at 591 .

43. Id. at 616-55. A single paragraph at the end of the opinion mentioned other uses, noting that the parties had agreed that the decree should not limit the use of water for "ordinary and usual domestic and municipal purposes." Id. at 656. The Court agreed and added livestock watering to the list at Wyoming's suggestion. Id. 
is a treasure, ${ }^{, 44}$ - the Court treated the North Platte River solely as a source of input for agricultural production.

Half a century later, Nebraska and Wyoming renewed their Supreme Court dispute over the waters of the North Platte. By the 1990s, environmental issues--particularly the need for instream flows to provide habitat for endangered birds along the Central Platte River in Nebraskahad become a major concern for states and water users throughout the basin. ${ }^{45}$ In returning to the Supreme Court, Nebraska initially "sought modification of the [1945] decree to make Wyoming and Colorado share the burden of providing instream flows necessary to preserve critical wildlife habitat, ${ }^{, 46}$ but the Court denied this motion without explanation. ${ }^{47}$ Later, however, the Court ruled that it would consider evidence of environmental injury in Nebraska in deciding whether to enjoin proposed upstream water projects. ${ }^{48}$ Because enjoining such projects would require the Court to modify its earlier decree, however, Nebraska would have to show substantial injury (environmental or otherwise) in order to obtain relief, a "far from insignificant" burden. ${ }^{49}$ Thus, the Court rejected Wyoming's argument that it should consider only evidence of injury to Nebraska's irrigators, not her wildlife ${ }^{50}$ But, through this limited holding, the Court declined to impose affirmative environmental obligations on the states, allowed Nebraska to introduce environmental evidence only for a limited purpose, and warned that it would not readily grant relief based on environmental injuries.

\section{B. Interstate Compacts: Upper Colorado and Klamath}

Many of the western United States' interstate rivers are allocated by compact, but this essay will focus on only two. The Upper Colorado River Basin Compact of 1949 allocates the "Upper" Colorado River" and its

44. N.J. v. N.Y., 283 U.S. 336, 342 (1931) (apportioning the waters of the Delaware River) (alteration added).

45. See John Echeverria, No Success Like Failure: The Platte River Collaborative Watershed Planning Process, 25 WM. \& MARY ENVTL L. \& POL'Y Rev. 559, 565-70 (2001) (describing history of Platte River Basin endangered species controversies in the 1980s through the mid-1990s).

46. Neb. v. Wyo., 515 U.S. 1, 12 (1995) (describing Nebraska's motion filed in 1988) (alteration added).

47. Id. (citing Neb. v. Wyo., 485 U.S. 931 (1988)).

48. The Court distinguished its earlier ruling: "To assign an affirmative obligation to protect wildlife is one thing; to consider all downstream effects of upstream development when assessing threats to equitable apportionment is quite another." $I d$. at 12.

49. Id. (citing Neb. v. Wyo., 507 U.S. 584, 592 (1993) (describing standards for enforcing versus modifying decree)).

50. Id. at 12-13.

51. The 1922 Colorado River Compact divided the basin between the "Upper" and "Lower" at Lee Ferry, a point on the Colorado River near the Arizona-Utah border and 
tributaries among the states of Colorado, New Mexico, Utah, and Wyoming. ${ }^{52}$ The Klamath River Basin Compact of 1957 addresses water allocation and management in the Klamath Basin of California and Oregon. ${ }^{53}$ Among the west's interstate water compacts, these two provide a fair degree of contrast. The Upper Colorado Basin contains some of the most arid parts of the interior west, ${ }^{54}$ and despite the popularity of angling in this area (especially for trout), fisheries have not traditionally been a major focus of water management. ${ }^{55}$ The Klamath Basin, by contrast, typically receives far more precipitation on average, ${ }^{56}$ and has long supported one of the most important salmon fisheries on the West Coast. ${ }^{57}$

The Upper Colorado Compact begins by stating its purposes, the last of which is "to secure the expeditious agricultural and industrial development of the Upper Basin, the storage of water and to protect life and property from floods." 58 This initial statement, by emphasizing water development for a few specified ends, indicates that the compact is not intended to serve environmental (or even recreational) values. Twenty more articles follow the statement of purposes-most famously, an article allocating a specific percentage of the basin's share of water to each of the four states ${ }^{59}$ - but none makes any mention of fish, wildlife, water quality, or recreation. The one non-consumptive use recognized by the compact is

allocated water to each basin rather than to individual states. Colorado River Compact, COLO. REV. STAT. § 37-61-101, art. II-III (2012).

52. Upper Colorado River Basin Compact, ch. 47-48, art. III, 63 Stat. 31 (1949). Part of Arizona is located in the Upper Basin, but that state received a fixed allocation of water that was much smaller than the states. Id. Arizona is primarily a "Lower Basin" state, along with California and Nevada. Map of Upper and Lower Basin States, High COUNTRY NEws, https://www.hen.org/blogs/range/images1/StateofArizona.jpg/view (last visited November 13, 2013, archived at http://perma.cc/0f7505U3tmA).

53. Klamath River Basin Compact, Pub. L. No. 85-222, 71 Stat. 497 (1957).

54. None of the four states in the Upper Colorado River Basin averages even sixteen inches of precipitation a year, making them among the driest states in the nation; Utah is the second driest state with an annual average of 12.26 inches per year, followed by Wyo. (3rd, 12.97"), N.M. (5th, 14.36"), and Colo. (7th, 15.97"). U.S. Dept. of Commerce, Total Precipitation in Inches by Month, EARTH SYSTEM RESEARCH LABORATORY, http://www.esrl.noaa.gov/psd/data/usclimdivs/pcp.state.19712000.climo.html (last visited Nov. 17, 2013, archived at http://perma.cc/0KWrbusHLQ6).

55. Having spent most of his career working on water issues in three of the four states of the Upper Colorado, the author has first-hand knowledge of this aspect of the water management.

56. Bureau of Reclamation, U.S. Dept. of the Interior, Secure Water act SeCtion 9503(C) - ReClamation Climate Change AND Water 2011 (2011), last visited Nov. 17, 2013, at 63-66, archived at http://perma.cc/0PqHFx7BrWW (showing average annual precipitation of nearly thirty-five inches).

57. DOREMUS \& TARLOCK, supra note 35 , at 30-33 (describing historical abundance, decline, and ongoing significance of Klamath Basin salmon runs).

58. Upper Colorado River Basin Compact, ch. 47-48, art. I(a), 63 Stat. 31 (1949).

59. The Compact allocates 51.75 percent of the basin's water to Colorado, 11.25 percent to New Mexico, 23 percent to Utah, and 14 percent to Wyoming. Id. at art. III(a)(2). 
hydropower generation; despite its economic and social value, however, hydropower is "subservient to the use and consumption of water for agricultural and domestic purposes and shall not interfere with or prevent use for such dominant purposes." ${ }^{60}$ Based on its plain text, the Upper Colorado Compact clearly prioritizes water development and use for conventional consumptive purposes, subordinates hydropower to these purposes, and simply ignores all others. ${ }^{61}$

The Klamath Compact has similar priorities but is far less singleminded. For starters, its purpose statement mentions not only consumptive uses, but also hydropower, navigation, and even "the protection and enhancement of fish, wildlife, and recreational resources. ${ }^{.62}$ The compact then recognizes all established rights to water in the Upper Klamath Basin, including irrigation and domestic rights in the Bureau of Reclamation's Klamath Project. ${ }^{63}$ Subject to these existing rights, the compact allows acquisition of new water rights under state law, and establishes the following priorities for such new rights: “(a) Domestic use, (b) Irrigation use, (c) Recreational use, including use for fish and wildlife, (d) Industrial use, (e) Generation of hydroelectric power, [and] (f) Such other uses as are recognized under the laws of the state involved." otherwise says little about fish and wildlife apart from a "miscellaneous" provision directing the states to use their authorities to regulate the flows downstream of hydropower projects "for protection of fish, human life or property from damage caused by fluctuations" resulting from project operations. ${ }^{65}$ In addition, a savings clause offers some protection for the federal government's use of water for "officially designated waterfowl

60. Id. at art. XV(a). "Domestic" use includes such disparate purposes as livestock, municipal, mining, milling, and industrial uses, as well as household water supply. Id. at art. II(m).

61. A savings provision declares that the compact does not alter the obligations of the United States to Indian tribes or to Mexico, or affect "any rights or powers of the United States of America, its agencies or instrumentalities, in or to the waters of the Upper Colorado River System, or its capacity to acquire rights in and to the use of said waters." Id. at art. $\mathrm{XIX}(\mathrm{a})-(\mathrm{c})$.

62. Klamath River Basin Compact, Pub. L. No. 85-222, art. I.A, 71 Stat. 497 (1957). These latter purposes actually appear in the middle of the purpose statement, after domestic and irrigation uses but before industrial uses, hydropower, navigation, and flood prevention. See id.

63. Id. at art. III.A. Article II defines key terms, including "Upper Klamath River Basin," "irrigation use," "domestic use," and "Klamath Project." Id. at art. II.

64. Id. at art. III.B.1 (alteration added). This preference list applies narrowly, however, to "conflicting applications to appropriate water when there is insufficient water to satisfy all such applications."

65. Id. at art. VIII.B. 
management areas."66 Finally, the compact addresses water pollution control, primarily leaving it up to the individual states but giving the Klamath River Compact Commission authority to address disputes over interstate water pollution. ${ }^{67}$

It should come as no surprise that the Klamath Compact recognizes the value of water for fish and wildlife, given the basin's important commercial, tribal, and sport fisheries, and its major national wildlife refuges that provide key habitats for migratory birds. ${ }^{68}$ The compact does not actually give much weight to these purposes, in that it prioritizes both existing water rights and new irrigation and domestic uses over "[r]ecreational use, including use for fish and wildlife." ${ }^{, 69}$ By specifically addressing these purposes and water quality, however, the Klamath Compact takes a broader view of water resources than many western interstate compacts. The Upper Colorado Compact, by contrast, simply ignores environmental issues- just like many others in the interior west. ${ }^{70}$

In short, decrees and compacts have allocated the waters of interstate rivers with little to no regard for fish, wildlife, or other environmental values. $^{71}$ This fact is hardly surprising, given that most western compacts

66. Id. at art. XI.E. This provision also preserves "rights and obligations" under the federal migratory bird laws. There are additional savings clauses regarding Indian water rights, but the only use they specifically address is irrigation. Id. at art. X.

67. Id. at art. VII.C. The Commission, which has one representative each from Oregon and California and one federal representative, is established under Article IX. Id. at art. IX.

68. For a brief summary of these and other Klamath Basin water uses, see Reed D. Benson, Giving Suckers (and Salmon) an Even Break: Klamath Basin Water and the Endangered Species Act, 15 TuL. ENVTL. L.J. 197, 201-06 (2002).

69. Klamath River Basin Compact, Pub. L. No. 85-222, art. III(b), 71 Stat. 497 (1957) (alteration added).

70. For example, there is no mention of fish, wildlife, water quality, or recreation in the Rio Grande Compact, ch. 155, 53 Stat. 785 (1939); Arkansas River Compact, ch. 155, 63 Stat. 145 (1949); or the Yellowstone River Compact, ch. 629, 65 Stat. 663 (1951). The Snake River Compact does contain one mention: it "protects" fish and wildlife by providing that, if a reservoir is constructed in one state (Wyoming) but its water is to be used in another state (Idaho), "sufficient water not to exceed five cubic feet per second shall be released at all times, if necessary for stock-water use and conservation of fish and wildlife." Snake River Compact, ch. 73, art. XI, 64 Stat. 29, 33 (1950) (emphasis added). Consider that the average mid-July flow in the Snake River at Moose, Wyoming, is around five thousand cubic feet per second. See USGS Surface-Water Daily Statistics for Wyoming, USGS, $\mathrm{http}: / /$ waterdata.usgs.gov/wy/nwis/dvstat? (last visited Nov. 8, 2013, archived at $\mathrm{http}: / /$ perma.cc/0WKFV8k6eFt) (median daily flow data for USGS Gauge 13013650).

71. This point does not suggest, however, that compacts and decrees have only negative environmental consequences. To the contrary, to the extent that a compact or decree requires an upstream state to deliver a certain amount or percentage of water in a river to a downstream state, that requirement effectively obligates the upstream state to preserve river flows at the minimum level needed to ensure compliance, resulting in incidental environmental benefits. The author has often hard former Wyoming State Engineer Jeff 
were enacted well before the "environmental decade" of the 1970s, when Congress enacted most of the landmark national environmental laws. ${ }^{72}$ Just because compacts and decrees failed to address environmental issues, however, does not mean that these issues have no relevance today in the management of western rivers, as the next section explains.

\section{ENVIRONMENTAL ISSUES IN WESTERN INTERSTATE RIVER MANAGEMENT}

\section{A. Examples of Agreements on River Management for Environmental} Purposes

Despite their absence from water compacts and decrees, environmental issues-specifically, the habitat needs of river-dependent species protected by the ESA-have become an increasingly important factor in the management of western interstate rivers. This is true in several river basins, each with its own issues and approach to dealing with them, but there is a strong trend toward multilateral agreements addressing water management and endangered species protection. ${ }^{73}$ Some of the more notable environmental agreements are found in the three basins discussed in the previous sections: ${ }^{74}$ the Platte, Upper Colorado, and Klamath. In each of these basins federal water projects operated by the Bureau (along with other water uses) have dramatically altered aquatic ecosystems, and several riverdependent species are now listed as threatened or endangered under the ESA. $^{75}$

The Platte River Basin ${ }^{76}$ is covered by a Recovery Implementation

Fassett make this point in explaining that Wyoming's interstate compacts and the North Platte decree provide a measure of instream flow protection within the state.

72. Building the "Environmental Decade," GAYLORD NELSON AND EARTH DAY, $\mathrm{http}: / /$ www.nelsonearthday.net/nelson/environmental-decade.htm (last updated Apr. 20, 2011 , archived at $\mathrm{http}: /$ www.perma.cc/0nmgGqCpUbZ).

73. See, e.g., supra note 61 and accompanying text.

74. See supra Part II.A-B.

75. From the standpoint of water management, the key listed species in these basins are the Colorado pikeminnow (formerly called squawfish), humpback chub, bonytail chub, and razorback sucker in the Upper Colorado Basin. U.S. DEP'T OF THE INTERIOR, FISH \& Wildlife Serv., Final Recovery Implementation Program for Endangered Fish SPECIES IN THE UPPER Colorado RIVER BASIN 1-3 (1987). The Platte River species are the whooping crane, interior least tern, piping plover, and pallid sturgeon. U.S. DEP'T OF THE Interior, Record of Decision, Platte River Recovery Implementation Program 1 (2006) [hereinafter PLATTE RIVER RIP]. In the Klamath Basin, the key listed species for water management are the Lost River sucker, shortnose sucker, coho salmon, green sturgeon, and eulachon. Letter from William W. Stelle Jr., Nat'l. Marine Fisheries Serv. \& Laurie R. Sada, U.S. Fish \& Wildlife Serv., to Jason Phillips, U.S. Bureau of Reclamation (May 31, 2013) (on file with author).

76. The Platte River is formed by the confluence of the North Platte and the South Platte in western Nebraska. The North Platte, as discussed above, is covered by an equitable 
Program (RIP), which was finalized in 2006 with the signing of a cooperative agreement by the Secretary of the Interior and the governors of Colorado, Nebraska, and Wyoming. ${ }^{77}$ This agreement was more than a decade in the making, requiring years of negotiation by federal, state, and stakeholder representatives. ${ }^{78}$ In essence, the Platte River RIP is a cooperative approach to habitat restoration for four ESA-listed species along the river in Nebraska; scientific estimations provide the quantity of river flows and riparian habitat these species require, and the RIP seeks to provide one-third of those quantities in its initial thirteen-year increment. ${ }^{79}$ While providing long-term environmental gains, the RIP also delivers immediate benefits for water users and managers by ensuring ESA compliance for existing and new water development activities. ${ }^{80}$ The program is funded by a combination of state and federal funds (although most of the actual dollars are federal), and steered by a "Governance Committee" involving federal and state officials, water users, and conservation groups. ${ }^{81}$ Congress provided authority and substantial funding for the Platte RIP in $2008 .^{82}$

The arrangements are similar for the Upper Colorado, which has not one but two RIPs: one for most of the Upper Colorado River Basin ${ }^{83}$ and another for a major tributary, the San Juan River. ${ }^{84}$ These programs were also established by formal cooperative agreements signed by federal officials and state governors, as well as Indian tribes in the case of the San Juan. ${ }^{85}$ As in the Platte, the Upper Colorado and San Juan RIPs serve a dual purpose, offering benefits to listed species and their habitat, while also

apportionment decree issued by the U.S. Supreme Court. See supra notes $39-44$ and accompanying text. The waters of the South Platte Basin are allocated between Colorado and Nebraska under one of the earliest interstate compacts. South Platte River Compact, ch. 46, 44 Stat. 195 (1926).

77. U.S. Dep't of the Interior, Platte River Recovery Implementation Program CoOperative Agreement (2006) [hereinafter Platte River Agreement].

78. Reed D. Benson, Avoiding Jeopardy, Without the Questions: Recovery Implementation Programs for Endangered Species in Western River Basins, 2 МicH. J. ENVTL. \& ADMIN. L. 473, 507-08 (2013) (explaining history of the Platte RIP's development).

79. Platte River RIP, supra note 75, at 4.

80. Benson, supra note 78, at 524-27 (summarizing benefits of RIPs, including reliable ESA compliance without litigation).

81. Id. at 510-13 (describing governance and funding of the Platte RIP).

82. Act of May 8, 2008, Pub. L. No. 110-229, § 515, 122 Stat. 754, 847-50 (authorizing up to $\$ 157$ million in federal funding).

83. See U.S. Dep't of the INTERIOR, Fish \& Wildlife SERV., Final ReCovery IMPLEMENTATION PROGRAM FOR ENDANGERED FISH SPECIES IN THE UPPER COLORAdO RIVER BASIN [hereinafter COLORADO] (1987).

84. U.S. Dep'T OF the INTERIOR, Fish \& Wildlife SERV., SAN Juan River Basin Recovery Implementation Program: Final Program Document [hereinafter San Juan] (2010).

85. Id. at 46-55; COOPERATIVE AGREEMENT fOR ReCOVERy IMPLEMENTATION PROGRAM FOR ENDANGERED SPECIES IN THE UPPER COLORADO RIVER BASIN (1988). 
providing reliable ESA compliance for water users, managers, and developers. ${ }^{86}$ Federal officials, states, and stakeholders share governance of the programs under decision rules that give substantial power to minority views. ${ }^{87}$ Finally, these two RIPs have found support and funding on Capitol Hill, even producing a rare moment of bipartisanship in the 112th Congress. ${ }^{88}$

The Klamath Basin presents a different story, as ESA compliance in that basin produced years of bitter litigation. Conflict reached a crescendo with the 2001 "water crisis" that saw many farmers on the Bureau of Reclamation's Klamath Project get little or no water, but the disputes had been brewing for years before then, both in and out of court. ${ }^{89}$ The following year, a new ten-year plan adopted by the Bush Administration returned water to Klamath Project irrigators, but was implicated in a massive salmon die-off in the Klamath River that September. ${ }^{90}$ The 2002 plan produced a fresh round of litigation, wherein courts threw out major elements of the plan. ${ }^{91}$ Thus, in the Klamath Basin, environmental issues initially became a key factor in water management through litigation. ${ }^{92}$

86. See Benson, supra note 78, at 508-10 (describing purposes of the RIPs), 513-16 (describing recovery actions), and 516-19 (describing how the RIPs ensure that water use and management activities comply with $\S 7$ of the ESA's requirements).

87. Id. at 512-13 (describing membership of the Upper Colorado RIP Recovery Implementation Committee, which makes decisions by consensus, and the San Juan RIP Coordination Committee, which requires a two-thirds vote for action).

88. Endangered Fish Recovery Programs Extension Act of 2012, Pub. L. No. 112-270, 126 Stat. 2444 (2013) (introduced with eight Republican and five Democratic cosponsors as H.R. 6060, 112th Cong. (2012)).

89. See Benson, supra note 68 , at $214-28$ (describing the 2001 water crisis and events preceding it).

90. See DoREMUS \& TARLOCK, supra note 35, at 118-42 (describing events of 2002, including the new plan, the salmon kill, and the related scientific disputes).

91. Pac. Coast Fed'n of Fishermen's Ass'ns v. Bureau of Reclamation, 426 F.3d 1082, 1089, 1093-95 (9th Cir. 2005).

92. Litigation was also the driving force for environmental action in other interstate river basins. In the Columbia-Snake River Basin, where several salmon runs were listed as threatened or endangered in the 1990s, the application of $\S 7$ of the ESA to the Federal Columbia River Power System has been actively litigated for nearly two decades. See, e.g., Idaho Dep't of Fish \& Game v. Nat'l Marine Fisheries Serv., 850 F. Supp. 886, 900 (D. Or. 1994), vacated as moot, 56 F.3d 1071 (9th Cir. 1995); Nat'l Wildlife Fed'n v. Nat'l Marine Fisheries Serv., 839 F. Supp. 2d 1117 (D. Or. 2011). In the Rio Grande Basin, litigation over the operation of Bureau projects in New Mexico effectively prompted federal action to protect the endangered Rio Grande silvery minnow. In one of the decisions in the silvery minnow litigation, U.S. District Judge Parker-while upholding the government's approach to operating the projects despite its risks to the minnow-still noted the positive impact of bringing the case:

It is my impression that at the time this lawsuit was filed, not much was being done by the federal agencies, or by the other major players with interests in the middle Rio Grande, to confront seriously the hard, difficult issues that had to be addressed in order to protect the minnow, and the river, itself. By filing 
More recently, however, even the Klamath Basin has given rise to a major negotiated agreement regarding water and endangered species, among other topics. ${ }^{93}$ The Klamath Basin Restoration Agreement (KBRA) was the product of three years of negotiations involving federal and state agencies (both Oregon and California), tribes, local governments, water users, and conservation groups. ${ }^{94}$ The KBRA was designed to produce "effective and durable solutions" that would restore and sustain natural fish populations throughout the basin, and also ensure reliable water and power supplies for agriculture and other uses. ${ }^{95}$ Existing irrigation was not fully protected, however, as the KBRA set limits on water diversions for USBR's Klamath Project that would result in deliveries about one hundred thousand acre-feet less than demand in very dry years. ${ }^{96}$ This wide-ranging and detailed agreement ${ }^{97}$ also addresses "regulatory assurances" including ESA compliance. ${ }^{98}$ The KBRA requires Congressional approval, however, and is currently stalled due to Tea Party opposition ${ }^{99}$ and concerns about its $\$ 800$ million federal price tag. ${ }^{100}$

Another collaborative, multilateral effort to address endangered species needs on an interstate river is the Multi-Species Conservation

this lawsuit, the Plaintiffs' attorneys got the ball rolling, prompting all interested parties to come up with far-reaching solutions to the problems that once seemed insurmountable.

Rio Grande Silvery Minnow v. Keys, 469 F. Supp. 2d 973, 1002 (D. N.M. 2002).

93. In fact, there are two major agreements, the Klamath Hydroelectric Settlement Agreement and the Klamath Basin Restoration Agreement. For a brief explanation of these agreements and the factors that contributed to their formation, see Hannah Gosnell \& Erin Clover Kelly, Peace on the River? Social-Ecological Restoration and Large Dam Removal in the Klamath Basin, USA, 3 WATER ALTERNATIVES, no. 2, 2010, at 362.

94. U.S. Dep'T OF the InTERIOR, Bureau of Reclamation, Summary: Klamath BASIN RESTORATION AGREEMENT 1, 10-11 (2010).

95. Id. at 1 .

96. $I d$. at 4.

97. The KBRA has nearly 40 sections covering over 170 pages, plus nearly 200 pages of appendices. See Bureau of Reclamation, U.S. Dep'T OF tHe INTERIOR, KLamath Basin

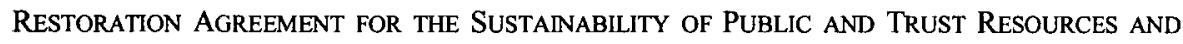
AFFECTED COMMUNIties (2010), last visited July 24, 2013, archived at http://www. klamathrestoration.gov/sites/klamathrestoration.gov/files/Klamath-Agreements/Klamath-

Basin-Restoration-Agreement-2-18-10signed.pdf.

98. Id. at 143-62 (the ESA material is at 153-59).

99. William Yardley, Tea Party Blocks Pact to Restore a West Coast River, N.Y. TIMES, July 18, 2012, at A16. The deal's opponents see the federal government as being more concerned with fish than farmers, and suggest that the KBRA is related to an environmentalist campaign to remove larger dams in the Columbia River system. Id.

100. Senator Ron Wyden, a Democrat from Oregon, recently announced that he had "concluded that the KBRA is simply unaffordable in the current budget environment." Amelia Templeton, Wyden: Klamath Basin Restoration Agreement is Too Expensive for Congress, NORTHWEST PUB. RADIO News, June 20, 2013, archived at http://perma.cc/0UyySkvrS8C. 
Program (MSCP) in the Lower Colorado River Basin. ${ }^{101}$ The MSCP has been described as "a cooperative effort between Federal and non-federal entities" that serves three purposes: "conserving habitat and working toward the recovery of threatened and endangered species, as well as reducing the likelihood of additional species being listed; accommodating present water diversions and power production and optimizing opportunities for future water and power development . . . ; and providing the basis for incidental take authorizations." 102 Thus, the MSCP is designed not only to benefit species and their habitat while allowing for ongoing and future water uses, but also to provide coverage against potential ESA liability for a variety of actors. Efforts to launch the MSCP date to 1995, when the Interior Department and state agency representatives from Arizona, California, and Nevada signed an initial agreement to develop the program. ${ }^{103}$ Today the MSCP includes these entities as well as dozens of water and power providers (primarily cities and special districts) in the three Lower Basin states. ${ }^{104}$

In sum, there are now several established environmental programsprimarily in the form of RIPs or other collaborative efforts-in western interstate river basins, even though the waters of these rivers were legally apportioned among the states with little or no regard for fish, wildlife, or other environmental needs. The next section offers some analysis of these programs in relation to the traditional forms of interstate water allocation.

\section{B. Environmental Efforts in Relation to Interstate Compacts and Decrees}

The endangered species initiatives in basins such as the Platte, Colorado, and Klamath, may suggest that the failure of interstate water allocation to address environmental concerns is now a moot point. A closer

101. The Lower Colorado is, famously, the only interstate stream allocated not by compact or Supreme Court decree, but by Congressional enactment. See Ariz. v. Cal., 373 U.S. 546 (1963) (holding that Congress apportioned the Lower Colorado in enacting the 1928 Boulder Canyon Project Act). Not surprisingly, neither the statute nor the Supreme Court decision mentions fish, wildlife, or other environmental issues in allocating water among the States of Arizona, California, and Nevada, although Arizona v. California did confirm that federal lands such as wildlife refuges may qualify for "reserved" water rights under federal law if water is needed to serve their purposes. Id. at 601 .

102. U.S. DeP'T OF THE INTERIOR, ReCORD OF DeCision, Lower Colorado MultiSPECIES CONSERVATION Plan 2 (2005) [hereinafter LOWER Colorado MUlTi-SPECIES CONSERVATION PLAN] (on file with author). The ESA normally prohibits any person from causing "take" of a listed species. 16 U.S.C. $\S 1539$ (a)(1)(B) (2012). However, the statute authorizes permits that allow "incidental take" caused by otherwise lawful activities, provided that certain requirements are met. 16 U.S.C. $\$ 1539$ (a) (2012). Thus, the MSCP is geared toward providing ESA compliance for a variety of non-federal water use and development activities.

103. Lower Colorado Multi-Species Conservation Plan, supra note 102, at 8.

104. Id. at 16 (listing participating entities from each of the three states). 
look at these programs as they relate to interstate compacts and decrees, however, suggests that they are at best a partial solution to the environmental challenges facing western rivers.

First, and most obviously, organized environmental efforts on interstate rivers are not equivalent to interstate compacts that have been approved by state legislatures and Congress. These programs do not take the form of new compacts, or even environmental amendments or addenda to existing compacts; they are designed and administered by groups that include stakeholders as well as federal and state entities, not by the compact commissions in the relevant river basins. ${ }^{105}$

This separation between the legal and institutional frameworks for interstate water allocation and for endangered species conservation might be unimportant if they were "separate but equal." In practice, however, the conservation programs represent a lower level of commitment than the compacts do. Compacts have the status of both state and federal statutes, but the conservation programs operate under cooperative agreements signed by government officials. ${ }^{106}$ Parties to these agreements may simply be able to withdraw unilaterally, ${ }^{107}$ whereas the right to withdraw from an established compact is uncertain at best. ${ }^{108}$ In addition, enforcement provisions are not always clear in cooperative agreements, ${ }^{109}$ while

105. See supra notes 77,78 and accompanying text.

106. See supra notes $77-81$ and accompanying text.

107. For example, when then-Governor Freudenthal "reluctantly" signed Wyoming onto the Platte River RIP in 2006, he noted "Wyoming could withdraw from the agreement if the other states and the federal government don't keep their promises." Press Release, Governor Dave Freudenthal, Governor Signs On to Platte River Agreement (Nov. 27, 2006) (on file with author). Similarly, the Klamath County Commission, which initially signed onto the KBRA, voted in 2013 to withdraw from the agreement. Associated Press, Klamath County Officials Vote to Drop Out of the Klamath Basin Restoration Agreement, OREGON LIVE (Feb. 27 , 2013), http://www.oregonlive.com/environment/index.ssf/2013/02/klamath_county_ officials_vote.html, archived at http://perma.cc/0Mh4YZqPgkf.

108. As stated by the U.S. Supreme Court in a case over the Ohio River Valley Water Sanitation Compact, "It requires no elaborate argument to reject the suggestion that an agreement solemnly entered into between States by those who alone have political authority to speak for a State can be unilaterally nullified, or given final meaning by an organ of one of the contracting States." West Virginia ex rel. Dyer v. Sims, 341 U.S. 22, 28 (1951). However, Professor Grant has argued that a state should always have power to withdraw from a compact. Grant, supra note 4, at 179.

109. For example, the federal-state cooperative agreement establishing the Platte RIP has a paragraph titled "Avoidance of Future Litigation," which among other things states the following:

If a signatory state has concerns that a Program-related activity is being implemented or operated in violation of an interstate water compact or decree with another signatory, attempts will be made within the context of the Program to resolve such concerns before any compact or decree enforcement action relating to that concern is taken before the United States Supreme Court or other judicial body. 
interstate compacts are directly enforceable in the US Supreme Court. ${ }^{110}$

Given these factors, and the western states' reliance on their compact rights and apportionments, it is hardly surprising that compacts have not given way to environmental requirements in the allocation and management of interstate waters. To the contrary, compacts are almost invariably seen as a legal constraint on the conservation programs, which are generally set up to operate subject to interstate compacts as well as other existing laws. ${ }^{11}$ Perhaps the best that can be said of the compacts is that they have not precluded environmental efforts, ${ }^{112}$ but have instead left the door open for the formation and operation of conservation programs.

A major shortcoming of these programs, however, is that they are almost entirely geared toward ESA compliance. Thus, protecting endangered species is far and away the most important environmental factor in the management of interstate rivers. This nearly exclusive emphasis on the ESA is a policy problem for several reasons. First, where there are no threatened or endangered species, there is little or no environmental progress; one example is the "Lower" Rio Grande in New Mexico, which has remained dry for months at a time in the reach between Elephant Butte Reservoir and the Texas border. ${ }^{113}$ Second, focusing solely on the ESA

PLATTE RIVER AGREEMENT, supra note 77, at 3-4. The cooperative agreements establishing the Upper Colorado and San Juan RIPs are silent on whether or how they may be enforced. See SAN JUAN, supra note 84; Colorado, supra note 83.

110. Several compact enforcement cases have reached the US Supreme Court in recent years. See, e.g., Tex. v. N.M., 462 U.S. 554 (1983) (Pecos River Compact); Kan. v. Colo., 514 U.S. 673 (1995) (Arkansas River Compact); Mont. v. Wyo., 131 S.Ct. 1765 (2011) (Yellowstone River Compact).

111. The cooperative agreements establishing the Upper Colorado and San Juan RIPs, supra notes 83,84 , state that they are "subject to" and "intended to be consistent with" all applicable laws, specifically including interstate compacts. See SAN JUAN, supra note 84; Colorado, supra note 83. The Platte Cooperative Agreement is even more thorough, declaring:

This Program Agreement is subject to and is intended to be consistent with all applicable federal and state laws and interstate compacts and decrees. Nothing in this Agreement or in any of the Program documents attached hereto shall be in any way construed as a modification of an interstate compact or decree or an abrogation or waiver by any state of rights under any such compact or decree.

Platte River AgREEMENT, supra note 77, at 3.

112. The exception may be the Lower Colorado River, where a court rejected arguments that the Bureau had a duty to "consult" under $\S 7$ of the ESA on the effect of its project operations on endangered species located in Mexico, holding that the "Law of the River"including the Colorado River Compact-left the Bureau no operating discretion that it could exercise for the benefit of those species. Defenders of Wildlife v. Norton, $257 \mathrm{~F}$. Supp. 2d 53, 57-8 (D. D.C. 2003). Even so, there is an ongoing Multi-Species Conservation Program (MSCP) that seeks to benefit fish and wildlife (including ESA-listed species) on the Lower Colorado. See supra notes 101-104 and accompanying text.

113. In the words of journalist and commentator John Fleck, on the Lower Rio Grande: 
means that other environmental factors-recreational fisheries, migratory birds, water quality, etc. - may get little or no attention even where listed species exist. Third, if water management is impervious to environmental demands except those backed by the ESA, then conservation groups are forced to turn to the ESA for leverage, creating powerful incentives to pursue new species listings.

The ESA has been uniquely effective in motivating cooperative efforts involving western water management, bringing federal agencies, states, and diverse stakeholders together. ${ }^{114}$ A key question for the west, however, is whether environmental improvements in interstate river management can extend beyond the needs of endangered species. A broader, more diversified river restoration effort could benefit the region in many ways, but such an effort seems unlikely without a strong legal mandate, and no existing law has been nearly as influential as the ESA. For their part, western interstate compacts and decrees certainly will not promote ecosystem restoration, ${ }^{115}$ but the movement towards endangered species conservation suggests that environmental progress may be possible in spite of them.

The silvery minnow is long gone. In that stretch of the Rio Grande, the river's job is to deliver water to farms and cities, and if that human end is well-served by shutting down flows in the winter to save water for spring planting, we do it without question. No one has batted an eye about leaving the Rio Grande itself dry for more than eight months so that water can be stored up for a short irrigation season.

John Fleck, Emerson, Nixon and the Silvery Minnow, ALBUQUERQUE JoURNAL NEWS, June 4, 2013, at A1.

114. I address this point in detail in a recent article, describing not only the RIPs on the Platte, Upper Colorado, and elsewhere, but other collaborative efforts such as the KBRA, the Lower Colorado MSCP, and a broad-based "Recovery Implementation Committee" on the Missouri River. Benson, supra note 78, at 501-4.

115. It is possible that Florida's promised litigation against Georgia in the United States Supreme Court, in which Florida argues that reduced instream flows in the Appalachicola River have harmed Appalachicola Bay and its economically important oyster fishery, may establish environmental injuries as a basis for relief under the equitable apportionment doctrine. See Supreme Court: Fla. Plans Legal Action to Stem Ga. Water Withdrawals, E\&E NEws PM, http://www.eenews.net/pm/2013/08/13 (Aug. 13, 2013, archived at http://perma.cc/0qK8Sh8U9mi). Even if it does, however, that precedent will have little or no significance for western rivers that have already been allocated by compact. 